\title{
Pengaruh Penambahan Puree Kacang Merah (Phaseolus vulgaris) Terhadap Karakteristik Nugget Jamur Tiram (Pleurotus ostreatus)
}

\section{The Effect of Adding Red bean (Phaseolus vulgaris) Puree Additions on the Characteristic of Oyster Mushroom (Pleurotus ostreatus) Nuggets}

\author{
Elsa Fanora Sinaga ${ }^{1}$, Putu Suparthana ${ }^{1^{*}}$, Ni Made Indri Hapsari A. ${ }^{1}$ \\ Program Studi Teknologi Pangan, Fakultas Teknologi Pertanian, Universitas Udayana \\ Kampus Bukit Jimbaran, Badung-Bali \\ *Penulis korespondensi: Putu Suparthana, Email: suparthana@unud.ac.id
}

\begin{abstract}
This study was aimed to determine the effect of adding red bean (Phaseolus vulgaris) puree to oyster mushroom nugget food and to see the correct amount of addition of red bean puree in producing oyster mushroom nuggets with the best criteria. The experimental design used in this research was a Completely Randomized Design (CRD) with an addition of red bean puree that consisted of 5 treatments namely: $0 \% ; 10 \% ; 20 \% ; 30 \%$; and $40 \%$. The treatment was repeated 3 times to obtain 15 experimental units. The data obtained were analyzed by variance and if the treatment had significant effect then followed by Duncan's Multiple Range Test (DMRT). The addition of red bean puree affected water content, ash content, protein content, crude fiber content, hedonic test (texture, aroma, taste and overall acceptance) and scoring test (texture). The addition of $40 \%$ red bean puree ratio of had the best characteristics with water content of $32,67 \%$, ash content of $1,57 \%$, protein content of $7,29 \%$, crude fiber content of $6,47 \%$, hedonic test (texture, taste and overall acceptance) was liked, aroma was disliked and scoring test of taste was chewy.
\end{abstract}

Keywords: nugget, Oyster Mushroom, red bean puree

\section{PENDAHULUAN}

Nugget adalah jenis makanan dengan bahan baku utama berupa daging yang digiling lalu dicetak dalam bentuk potongan persegi empat dan dilapisi dengan tepung panir. Nugget diminati oleh banyak kalangan masyarakat dimulai dari kalangan anak-anak hingga kalangan dewasa. Hal ini dikarenakan rasa nugget yang enak, mudah dan praktis cara penyajiannya. Bahan dasar yang digunakan dalam pengolahan nugget adalah bahan yang memiliki kandungan protein cukup tinggi, seperti daging ayam, daging sapi dan ikan. Alamsyah (2007) menyatakan bahwa pengolahan nugget tidak hanya memanfaatkan bahan dasar dari produk hewani saja, melainkan dapat memanfaatkan bahan dasar dari produk nabati seperti jamur tiram. Jamur tiram merupakan salah satu bahan nabati yang cukup populer di Indonesia, jamur tiram mudah diperoleh karena keberadaannya tidak tergantung musim sehingga relatif mudah dibudidayakan.

Saragih (2015) menyatakan bahwa jamur tiram memiliki potensi pengganti daging dikarenakan memiliki karakteristik fisik yang kenyal dan lembut hampir menyerupai tekstur daging ayam. Nutrisi jamur tiram putih per 100 gram terdiri atas kandungan protein 5,94\%, serat 1,56\%, lemak 0,17\%, karbohidrat 50,59\%, 45,65 kalori, zat besi 1,9 mg, kalsium 8,9 mg, vitamin B1 0,75 mg, vitamin B2 0,75 mg, vitamin C 12,4 mg, dan Fosfor 17 mg (Chazali, 2009), dan kandungan 
airnya sebesar 60\% (Achmad, 2011). Akan tetapi, jamur tiram memiliki kandungan protein yang rendah, sehingga perlu menambahkan bahan lain untuk meningkatkan kadar protein pada nugget, salah satunya adalah kacang merah.

Kacang merah merupakan salah satu jenis polong-polongan (legume) yang diproduksi sekitar 103.376 ton pada tahun 2013 di Indonesia (Badan Pusat Statistik, 2014). Mahmud et.al., (2018) menyatakan bahwa 100 g kacang merah kering mengandung karbohidrat $56,6 \%$, protein $10,0 \mathrm{~g}$ dan serat 3,5 g. Tingginya kandungan protein pada kacang merah mampu meningkatkan protein dalam nugget jamur tiram dan tingginya kandungan karbohidrat pada kacang merah dapat dimanfaatkan sebagai bahan pengisi dalam pembentukan teksutr nugget jamur tiram.

Soeparno (1994) menyatakan bahwa selama proses pengolahan nugget terdapat 2 jenis bahan penting, yaitu bahan pengikat dan bahan pengisi. Bahan pengisi adalah bahan dengan kandungan karbohidrat yang memiliki kemampuan mengikat sejumlah air, tetapi memiliki pengaruh yang kecil terhadap emulsifikasi. Salah satu bahan yang dapat digunakan sebagai bahan pengisi adalah kacang merah dengan kandungan karbohidrat sebesar 56,6\% (Mahmud et.al., 2018). Bahan pengikat adalah bahan non daging yang memiliki fungsi menaikkan daya ikat protein terhadap air dan lemak sehingga emulsi tetap stabil. Pada umumnya bahan pengikat yang digunakan dalam pengolahan nugget adalah tapioka. Berdasarkan hal tersebut, dilakukan penelitian mengenai pengaruh penambahan puree kacang merah sebagai bahan pengisi terhadap karakteristik nugget jamur tiram.

\section{METODE PENELITIAN}

\section{Tempat dan Waktu}

Penelitian ini dilakukan di Laboratorium Analisis Pangan, Laboratorium Pengolahan Pangan, Laboratorium Pasca Panen dan Laboratorium Bioindustri dan Lingkungan, Fakultas Teknologi Pertanian, Universitas Udayana. Waktu penelitian ini berlangsung dari September 2020 sampai November 2020.

\section{Bahan dan Alat}

Bahan yang digunakan pada penelitian ini dibagi menjadi 2, yaitu bahan pengolahan nugget dan bahan analisis kimia. Bahan untuk pengolahan nugget terdiri dari jamur tiram yang segar yang diperoleh dari Pasar Senggol, Bukit Jimbaran, kacang merah kering, tapioka (Rose Brand), jahe, lada (Ladaku), bawang merah, bawang putih, garam telur ayam (yang digunakan bagian putih telur saja) dan tepung panir yang diperoleh dari Toko Kurnia, Puri Gading, Bukit Jimbaran. Es batu (yang digunakan air es) yang diperoleh dari Cocomart, Denpasar. Bahan kimia yang digunakan dalam melakukan analisis yaitu aquades, $\mathrm{H} 2 \mathrm{SO} 4$ (Merck), $\mathrm{NaOH}$ (Merck), $\mathrm{HCl}$ (Merck), H3BO3 dan Phenophtalein.

Alat-alat yang digunakan dalam penelitian ini dibagi menjadi dua yaitu alat untuk mengolah nugget dan alat analisis karakteristik nugget. Alat yang digunakan dalam pengolahan nugget yaitu timbangan digital (Tanita), blender (Miyako), talenan, pisau, gelas ukur (Pyrex), baskom, wajan, kompor (Rinnai), panci pengukus, chiller dan spatula. Alat yang digunakan untuk analisis karakteristik nugget yaitu timbangan analitik (Shimadzu), lumpang, kertas saring, kertas 
whatman 42, corong, oven (Memmert), cawan porselin, cawan aluminium, aluminium foil (Best fresh), pinset, pipet tetes, spatula, pipet volume (Pyrex), labu ukur (Pyrex), Erlenmeyer (Pyrex), gelas beaker (Pyrex), gelas ukur (Pyrex), pompa karet, labu takar (Pyrex), water bath (Thermology), muffle, desikator dan buret.

\section{Rancangan Penelitian dan Analisa Data}

Rancangan percobaan yang digunakan dalam penelitian ini adalah Rancangan Acak Lengkap (RAL) dengan perlakuan penambahan puree kacang merah terdiri dari 5 taraf, yaitu:

$\mathrm{P} 0=$ Puree kacang merah $0 \%$

$\mathrm{P} 1=$ Puree kacang merah 10\%

P2 $=$ Puree kacang merah 20\%

P3 = Puree kacang merah 30\%

$\mathrm{P} 4=$ Puree kacang merah $40 \%$

Masing-masing perlakuan diulang sebanyak 3 kali sehingga diperoleh 15 unit percobaan. Data yang diperoleh dari hasil penelitian dianalisis dengan sidik ragam dan apabila perlakuan berpengaruh terhadap variable maka dilanjutkan dengan uji Duncan (Steel dan Torrie, 1993).

\section{Pelaksanaan Penelitian}

Tahap pelaksanaan penelitian meliputi dua proses yaitu proses pembuatan puree kacang merah dan proses pembuatan nugget jamur tiram.

\section{Proses Pembuatan Puree Kacang Merah}

Proses pembuatan puree kacang merah dilakukan berdasarkan Huda dan Palupi (2015) yang telah dimodifikasi, yang diawali dengan mensortasi kacang merah dari sisa-sisa kulit serta bahan asing lainnya yang terikut kedalam kemasan kacang merah, kacang merah dicuci menggunakan air mengalir, kemudian dilakukan perendaman pada kacang merah selama 6 jam, kemudian pencucian kembali, setelah itu dilakukan steam blancing selama 2 menit pada suhu $70^{\circ} \mathrm{C}$ dengan tujuan meminimalisir hilangnya komponen yang larut air seperti flavor, warna, vitamin, mineral dan gula (Purwoko, 2009). Feri dan Tieitik (2018) menyatakan bahwa steam blanching dapat menyebabkan tekstur bahan menjadi lebih lunak akibat uap panas. Tahap berikutnya yaitu pendinginan menggunakan air es selama 2 menit yang bertujuan untuk menghentikan proses pematangan, jika bahan dalam keadaan panas proses pematangan pada bahan masih tetap berlangsung maka akan mempengaruhi kandungan gizi pada kacang merah. Tahap terakhir yaitu penghalusan kacang merah menggunakan blender.

\section{Pembuatan Nugget Jamur Tiram}

Proses pembuatan nugget jamur tiram dilakukan berdasarkan Saragih (2015) yang telah dimodifikasi. Proses pengolahan nugget jamur tiram diawali dengan pensortiran jamur tiram segar, bagian yang diambil dimulai dari bagian tengah batang hingga keseluruhan tudung jamur dicuci terlebih dahulu, kemudian dilanjutkan dengan pengecilan ukuran, batang dibelah dua dan tudung jamur dibagi menjadi 4 bagian dengan tujuan mempercepat uap panas mengenai keseluruhan jamur pada saat steam blanching berlangsung, selanjutnya dilakukan steam blanching pada suhu $70^{\circ} \mathrm{C}$ selama 2 menit dengan tujuan meminimalisir hilangnya komponen yang larut air seperti flavor, warna, vitamin, mineral dan gula (Purwoko, 2009). Tahap selanjutnya yaitu 
pendinginan dengan menggunakan air es selama 2 menit dengan tujuan untuk menghentikan proses menghentikan suhu panas yang mempengaruhi kandungan gizi pada bahan. Tahap selanjutnya pencampuran dan penghalusan bahan seperti kacang merah, jamur tiram,bawang merah, bawang putih, tapioka, jahe, merica bubuk, garam dan es batu menggunakan blender sehingga menghasilkan adonan.. Penambahan es batu ke dalam adonan ditujukan untuk mempertahankan suhu akibat gesekan sehingga protein tidak terdenaturasi dan mempermudah proses penghalusan bahan. Tahap selanjutnya pembentukan adonan dengan panjang $2 \mathrm{~cm}$, lebar $2 \mathrm{~cm}$ dan tinggi $2 \mathrm{~cm}$, dan dilanjutkan proses pengukusan selama 15 menit pada suhu $70^{\circ} \mathrm{C}$, kemudian dilakukan pendinginan selama 10 jam di ruang pendingin (chiller) pada suhu $18^{0} \mathrm{C}$. Pelapisan adonan dilakukan 2 kali dengan bahan pelapis pertama menggunakan putih telur dan pelapis kedua tepung panir. Formulasi nugget jamur tiram dapat dilihat pada Tabel 1.

\section{Variabel yang diamati}

Variabel yang diamati dalam penelitian ini adalah kadar air dengan metode pengeringan, kadar abu dengan metode pengabuan langsung, penentuan kadar serat kasar dengan metode hidrolisis asam basa, analisis kadar protein dengan metode Kjeldahl (Sudarmadji et al., 1997), dan evaluasi sensoris diuji dengan uji hedonik (aroma, rasa, tekstur dan Penerimaan keseluruhan) serta uji skoring terhadap tekstur (Soekarto, 1985).

\section{Tabel 1. Formula Nugget Jamur Tiram}

\begin{tabular}{|c|c|c|c|c|c|c|}
\hline \multirow[t]{2}{*}{ No } & \multirow[t]{2}{*}{ Komposisi } & \multicolumn{5}{|c|}{ Perlakuan } \\
\hline & & P0 & P1 & $\mathrm{P} 2$ & P3 & P4 \\
\hline 1 & Jamur Tiram $(\%)$ & 100 & 100 & 100 & 100 & 100 \\
\hline 2 & Puree kacang Merah (\%) & 0 & 10 & 20 & 30 & 40 \\
\hline 3 & Tapioka (\%) & 20 & 20 & 20 & 20 & 20 \\
\hline 4 & Es Batu (\%) & 30 & 30 & 30 & 30 & 30 \\
\hline 5 & Garam (\%) & 1.2 & 1,2 & 1,2 & 1,2 & 1,2 \\
\hline 6 & Bawang Merah (\%) & 10 & 10 & 10 & 10 & 10 \\
\hline 7 & Bawang Putih (\%) & 6 & 6 & 6 & 6 & 6 \\
\hline 8 & Merica Bubuk (\%) & 0,2 & 0,2 & 0,2 & 0,2 & 0,2 \\
\hline 9 & Jahe $(\%)$ & 1 & 1 & 1 & 1 & 1 \\
\hline \multicolumn{7}{|c|}{ Bahan Pelapis } \\
\hline & Tepung Panir (gr) & 40 & 40 & 40 & 40 & 40 \\
\hline & Putih Telur (gr) & 40 & 40 & 40 & 40 & 40 \\
\hline
\end{tabular}

Keterangan : Persentase diatas berdasarkan berat jamur tiram 50g

\section{HASIL DAN PEMBAHASAN}

\section{Hasil Analisis Bahan Baku}

Hasil analisis nilai rata-rata kadar air, kadar abu, kadar serat kasar dan kadar Protein Puree kacang merah yang digunakan dapat dilihat pada Tabel 2 . Berdasrkan Tabel. 2 hasil uji yang didapatkan pada puree kacang merah. Menurut Mahmud et.al., 
(2018) menyatakan bahwa 100 g kacang merah kering mengandung karbohidrat 56,6\%. Nilai ratarata kadar air, kadar abu, kadar serat kasar dan kadar protein puree kacang merah pada Tabel. 2.

\section{Hasil Analisis Nugget Jamur Tiram}

Adapun hasil analisis nilai rata-rata kadar air, kadar abu, kadar serat kasar dan kadar protein nugget jamur tiram dengan penambahan puree kacang merah dapat dilihat pada Tabel 3.

Tabel 2. Nilai rata-rata kadar air, kadar abu, kadar serat kasar dan kadar protein puree kacang merah.

\begin{tabular}{|c|c|}
\hline Komponen & Puree Kacang Merah \\
\hline Kadar Air (\%) & 26,50 \\
\hline Kadar Abu (\%) & 1,19 \\
\hline Kadar Protein (\%) & 8.41 \\
\hline Kadar Serat Kasar (\%) & 4,79 \\
\hline
\end{tabular}

Tabel 3. Nilai rata-rata kadar air, kadar abu, kadar serat kasar dan kadar protein nugget jamur tiram

\begin{tabular}{ccccc}
\hline Perlakuan & Kadar Air (\%) & Kadar Abu (\%) & Kadar Protein (\%) & $\begin{array}{c}\text { Kadar serat kasar } \\
(\%)\end{array}$ \\
\hline $0 \%$ & $24,68 \pm 0.23 \mathrm{e}$ & $1,16 \pm 0.02 \mathrm{e}$ & $2,67 \pm 0.23 \mathrm{e}$ & $3,37 \pm 0.01 \mathrm{e}$ \\
$10 \%$ & $26,63 \pm 0.34 \mathrm{~d}$ & $1,29 \pm 0.00 \mathrm{~d}$ & $3,65 \pm 0.22 \mathrm{~d}$ & $4,12 \pm 0.03 \mathrm{~d}$ \\
$20 \%$ & $28,51 \pm 0.15 \mathrm{c}$ & $1,34 \pm 0.00 \mathrm{c}$ & $4,48 \pm 0.24 \mathrm{c}$ & $4,90 \pm 0.02 \mathrm{c}$ \\
$30 \%$ & $30,73 \pm 0.03 \mathrm{~b}$ & $1,44 \pm 0.00 \mathrm{~b}$ & $5,75 \pm 0.24 \mathrm{~b}$ & $5,73 \pm 0.00 \mathrm{~b}$ \\
$40 \%$ & $32,67 \pm 0.14 \mathrm{a}$ & $1,57 \pm 0.02 \mathrm{a}$ & $7,29 \pm 0.24 \mathrm{a}$ & $6,47 \pm 0.04 \mathrm{a}$ \\
\hline
\end{tabular}

Keterangan : Nilai rata-rata yang diikuti oleh huruf yang berbeda pada kolom yang sama menunjukkan berbeda nyata $(\mathrm{P}<0,05)$.

\section{Kadar Air}

Hasil sidik ragam menunjukkan bahwa penambahan puree kacang merah berpengaruh nyata $(\mathrm{P}<0,05)$ terhadap kadar air nugget jamur tiram. Tabel 3. menunjukkan nilai rata-rata kadar air nugget jamur tiram berkisar antara $24,68 \%$ sampai dengan $32,67 \%$. Nilai rata-rata kadar air tertinggi terdapat pada perlakuan P4 (puree kacang merah $40 \%$ ) sebesar $32,67 \%$ dan nilai rata-rata kadar air terendah terdapat pada perlakuan P0 (puree kacang merah 0\%) sebesar 24,68\%. Berdasarkan data diatas dapat diketahui bahwa penambahan puree kacang merah dapat meningkatkan kadar air nugget jamur tiram.
Mahmud et.al., (2018) menyatakan bahwa kacang merah memiliki kandungan karbohidrat sebesar $56,6 \%$. Salah satu jenis karbohidrat yang terkandung pada kacang merah adalah pati. Winarno (2004) menyatakan bahwa pati akan cenderung menyerap air, jika kandungan amilosa rendah dan kandungan amilopektin tinggi. Hal ini disebabkan adanya proses pemanasan yang tinggi akan menyebabkan pembengkakan granula pati yang juga diikuti dengan peningkatan viskositas dimana terjadi penguapan sehingga menyebabkan pori-pori pada adonan lebih banyak terbentuk sehingga kesempatan air masuk kedalam pori-pori semakin tinggi. 


\section{Kadar Abu}

Kadar abu berkaitan dengan kandungan mineral dalam bahan yang digunakan pada pengolahan nugget. Menurut Andarwulan et al., (2011) mineral pada suatu bahan ditunjukkan dari kadar abu yang terdapat dalam bahan tersebut. Hasil sidik ragam menunjukkan bahwa penambahn puree kacang merah berpengaruh nyata $(\mathrm{P}<0,05)$ terhadap kadar abu nugget jamur tiram. Tabel 3. menunjukkan nilai rata-rata kadar abu nugget jamur tiram berkisar antara $1,16 \%-1,57 \%$. Nilai rata-rata kadar abu terendah terdapat pada perlakuan P0 (puree kacang merah 0\%) sebesar $1,16 \%$ dan nilai rata-rata kadar abu tertinggi terdapat pada perlakuan P4 (puree kacang merah 40\%) sebesar 1,57\%. Semakin tinggi penambahan puree kacang merah maka kadar abu nugget jamur tiram juga akan semakin tinggi. Hal ini dikarenakan kadar abu puree kacang merah yang diperoleh lebih tinggi dari pada kadar abu nugget jamur tiram P0 (puree kacang merah 0\%). Berdasarkan hasil uji kadar abu pada puree kacang merah mengandung kadar abu sebesar1,19\% (Tabel 2). Peningkatan kadar abu pada nugget jamur tiram menunjukkan bertambahnya kandungan mineral pada nugget jamur tiram seiring dengan penambahan puree kacang merah.

\section{Kadar Protein}

Hasil sidik ragam menunjukkan bahwa penambahan puree kacang merah berpengaruh nyata $(\mathrm{P}<0,05)$ terhadap kadar protein dari nugget jamur tiram. Tabel 3. menunjukkan nilai rata-rata kadar protein pada nugget jamur tiram berkisar $2.67 \%-7,29 \%$. Nilai rata-rata kadar protein terendah terdapat pada perlakuan P0 (puree kacang merah $0 \%$ ) sebesar $2,67 \%$ dan nilai rata-rata tertinggi pada perlakuan P4 (puree kacang merah 40\%) sebesar 7,29\%. Semakin tinggi penambahan puree kacang merah, maka kadar protein pada nugget jamur tiram akan semakin tinggi. Hal ini dikarenakan kadar protein yang terkandung pada puree kacang merah lebih tinggi dibandingkan dengan kadar protein pada $\mathrm{P} 0$ (puree kacang merah $0 \%$ ). Berdasarkan hasil nilai rata-rata kadar protein yang terkandung pada puree kacang merah yaitu sebesar 8,41\% dan P0 (puree kacang merah 0\%) sebesar 2,67\%. Peningkatan kadar protein pada nugget jamur tiram dipengaruhi oleh tingkat penambahan puree kacang merah yang ditambahkan kedalam nugget jamur tiram.

\section{Kadar Serat Kasar}

Hasil sidik ragam menunjukkan bahwa penambahan puree kacang merah berpengaruh nyata $(\mathrm{P}<0,05)$ terhadap kadar serat kasar dari nugget jamur tiram. Tabel 3. menunjukkan nilai rata-rata kadar serat kasar pada nugget jamur tiram berkisar 3,37\% - 6,47\%. Nilai rata-rata kadar serat terendah terdapat pada perlakuan P0 (puree kacang merah $0 \%$ ) sebesar $3,37 \%$ dan nilai rata-rata tertinggi pada perlakuan P4 (puree kacang merah $40 \%$ ) sebesar $6,47 \%$. Hasil data menunjukkan kadar serat pada nugget jamur tiram mengalami peningkatan seiring dengan tingginya penambahan puree kacang merah yang ditambahkan.

Berdasarkan analisis bahan baku, puree kacang merah memiliki kadar serat kasar sebesar 4,79\%. Penelitian yang telah dilakukan Suharjo (2008) menyatakan bahwa jamur tiram putih memiliki kadar serat sebesar 1,56\%. Meningkatnya 
kadar serat kasar pada nugget jamur tiram dipengaruhi oleh tingkat penambahan puree kacang merah yang ditambahkan dalam pengolahan nugget jamur tiram. Semakin tinggi penambahan puree kacang merah maka kadar serat yang terkandung pada nugget jamur tiram akan semakin meningkat.

\section{Evaluasi Sensoris}

Evaluasi sensoris nugget jamur tiram dengan uji hedonik terhadap aroma, tekstur, rasa dan penerimaan keseluruhan. Uji skoring (tingkat kekenyalan) dilakukan terhadap tektur nugget jamur tiram. Nugget jamur tiram yang disajikan kepada panelis dalam keadaan sudah digoreng dengan ukuran panjang $2 \mathrm{~cm}$, lebar $2 \mathrm{~cm}$ dan tinggi $2 \mathrm{~cm}$. Nugget jamur tiram disajikan ke panelis tanpa melibatkan food carrier, namun menggunakan air mineral sebagai penetral mulut panelis. Nilai rata-rata uji hedonik aroma, rasa, tekstur dan penerimaan keseluruhan dan uji skoring tekstur dapat dilihat pada Tabel 4.

Tabel 4. Nilai rata-rata uji hdeonik aroma, tekstur, rasa dan penerimaan keseluruhan; uji skoring (Tekstur)

\begin{tabular}{lccccc}
\hline $\begin{array}{c}\text { Penambahan } \\
\text { Puree } \text { kacang } \\
\text { merah }\end{array}$ & \multicolumn{2}{c}{ Nilai Rata-Rata Uji Hedonik } & Uji Skoring & \multicolumn{2}{c}{ Uji Hedonik } \\
\cline { 2 - 6 } & Aroma & Tekstur & Tekstur & Rasa & $\begin{array}{c}\text { Penerimaan } \\
\text { Keseluruhan }\end{array}$ \\
\hline P0 (0\%) & $4,25 \pm 0,61 \mathrm{a}$ & $1,70 \pm 0,57 \mathrm{e}$ & $1,30 \pm 0,47 \mathrm{e}$ & $3,50 \pm 0,51 \mathrm{~b}$ & $1,45 \pm 0,51 \mathrm{e}$ \\
P1 (10\%) & $4,20 \pm 0,63 \mathrm{a}$ & $2,25 \pm 0,63 \mathrm{~d}$ & $1,75 \pm 0,44 \mathrm{~d}$ & $3,55 \pm 0,51 \mathrm{~b}$ & $2,20 \pm 0,76 \mathrm{~d}$ \\
P2 (20\%) & $3,65 \pm 0,67 \mathrm{~b}$ & $2,75 \pm 0,44 \mathrm{c}$ & $2,55 \pm 0,51 \mathrm{c}$ & $3,65 \pm 0,48 \mathrm{~b}$ & $3,30 \pm 0,47 \mathrm{c}$ \\
P3 (30\%) & $2,65 \pm 0,50 \mathrm{c}$ & $3,30 \pm 0,73 \mathrm{~b}$ & $3,45 \pm 0,51 \mathrm{~b}$ & $4,20 \pm 0,61 \mathrm{a}$ & $3,90 \pm 0,55 \mathrm{~b}$ \\
P4 (40\%) & $2,60 \pm 0,58 \mathrm{c}$ & $4,35 \pm 0,58 \mathrm{a}$ & $4,35 \pm 0,48 \mathrm{a}$ & $4,25 \pm 0,78 \mathrm{a}$ & $4,50 \pm 0,51 \mathrm{a}$ \\
\hline
\end{tabular}

Keterangan : Nilai rata-rata yang diikuti oleh huruf yang berbeda pada kolom yang sama menunjukkan berbeda nyata $(\mathrm{P}<0,05)$.

Kriteria Hedonik: Sangat suka $=5 ;$ Suka $=4 ;$ Biasa $=3$; Tidak suka $=2 ;$ Sangat tidak suka $=1$

Kriteria Skoring : Sangat kenyal $=5 ;$ Kenyal $=4 ;$ Agak kenyal $=3$; Tidak kenyal $=2$; Sangat tidak kenyal $=1$

\section{Aroma}

Berdasarkan hasil sidik ragam menunjukkan bahwa penambahan puree kacang merah berpengaruh nyata $(\mathrm{P}<0,05)$ terhadap aroma (uji hedonik) nugget jamur tiram. Tabel 4. menunjukkan nilai kesukaan tertinggi terhadap aroma nugget jamur tiram terdapat pada P0 (puree kacang merah $0 \%$ ) sebesar 4,25 dengan kriteria suka. Nilai kesukaan terendah terhadap aroma nugget jamur tiram terdapat pada perlakuan P4 (puree kacang merah 40\%) sebesar 2,60 dengan kriteria tidak suka dan tidak berbeda nyata dengan perlakuan P3 (puree kacang merah 30\%) sebesar 2,60 dengan kriteria tidak suka. Semakin tinggi penambahan puree kacang merah maka aroma nugget jamur tiram semakin tidak diminati oleh panelis. Panelis lebih menyukai aroma nugget jamur tiram dengan perlakuan tanpa penambahan puree kacang merah. Hal ini dikarenakan jamur tiram putih memiliki kandungan asam glutamat yang dapat meningkatkan aroma dan cita rasa 
masakan menjadi lebih gurih atau umami (Achmad, 2013).

\section{Tekstur}

Berdasarkan hasil sidik ragam menunjukkan bahwa penambahan puree kacang merah berpengaruh nyata $(\mathrm{P}<0,05)$ terhadap tekstur (uji hedonik) nugget jamur tiram. Tabel 4. menunjukkan nilai kesukaan tertinggi terhadap tekstur nugget jamur tiram terdapat pada P4 (puree kacang merah 40\%) sebesar 4,35 dengan kriteria suka. Nilai kesukaan terendah terhadap tekstur nugget jamur tiram terdapat pada perlakuan P0 (puree kacang merah 0\%) sebesar 1,30 dengan kriteria tidak suka. Hal ini dipengaruhi oleh tingkat penambahan puree kacang merah, semakin tinggi penambahan puree kacang merah maka tingkat kesukaan tekstur pada nugget jamur tiram akan semakin disukai panelis.

Berdasarkan hasil sidik ragam menunjukkan bahwa penambahan puree kacang merah berpengaruh nyata $(\mathrm{P}<0,05)$ terhadap tekstur (tingkat kekenyalan) nugget jamur tiram. Tabel 4. menunjukkan nilai kekenyalan tertinggi terhadap tekstur nugget jamur tiram terdapat pada P4 (puree kacang merah $40 \%$ ) sebesar 4,50 yaitu kenyal. Nilai kekenyalan terendah terhadap tekstur nugget jamur tiram terdapat pada perlakuan P0 (puree kacang merah $0 \%$ ) sebesar yaitu 1,70 sangat tidak kenyal. Menurut Widjanarko et al,. (2011) tekstur nugget sangat dipengaruhi oleh tingginya kandungan protein pada bahan yang digunakan dalam pembuatan nugget. Bintoro (2008), menyatakan bahwa nugget dengan kadar protein yang rendah akan menyebabkan rendahnya daya ikat air dan lemak. Kemampuan mengikat air dan lemak ini yang akan mempengaruhi tekstur nugget yang dihasilkan. Gaman dan Sherrington (1994) menambahkan protein yang terdenaturasi akibat proses pemanasan mengakibatkan koagulasi protein yaitu protein menjadi kental dan tidak mudah larut sehingga membentuk tekstur yang kenyal dan kokoh.

\section{Rasa}

Rasa bahan pangan menjadi salah satu indikator penting yang menentukan daya terima konsumen terhadap suatu produk, walau parameter penilaian yang lain lebih baik, jika rasa makanan tidak disukai panelis maka produk tersebut ditolak. Berdasarkan hasil sidik ragam menunjukkan bahwa penambahan puree kacang merah berpengaruh nyata $(\mathrm{P}<0,05)$ terhadap rasa (uji hedonik) nugget jamur tiram. tabel 4. menunjukkan nilai kesukaan terendah terhadap rasa nugget jamur tiram diperoleh pada perlakuan P0 (puree kacang merah $0 \%$ ) sebesar 3,50 dan tidak berbeda nyata dengan P1 (puree kacang merah 3,55) dengan kriteria biasa. Nilai kesukaan tertinggi diperoleh pada perlakuan P4 (puree kacang merah 40\%) sebesar 4,25 dengan kriteria suka. Hal ini dipengaruhi oleh tingkat penambahan puree kacang merah, semakin tinggi penambahan puree kacang merah, maka rasa terhadap nugget jamur tiram semakin disukai oleh panelis. Saragih (2015) menyatakan terbentuknya rasa pada bahan pangan dipengaruhi oleh komponen yang ada dalam bahan dan proses yang dialami. Rasa nugget jamur tiram yang digoreng terbentuk akibat pemanasan komponen protein, karbohidrat, lemak dan 
komponen lainnya yang ada dalam bahan pangan tersebut.

\section{Penerimaan Keseluruhan}

Berdasarkan hasil sidik ragam menunjukkan bahwa penambahan puree kacang merah berpengaruh nyata $(\mathrm{P}<0,05)$ terhadap penerimaan keseluruhan (uji hedonik) nugget jamur tiram. Tabel 4. menunjukkan nilai penerimaan keseluruhan nugget jamur tiram tertinggi diperoleh pada perlakuan P4 (puree kacang merah 40\%) sebesar 4,50 dengan kriteria suka. Nilai penerimaan keseluruhan terendah nugget jamur tiram diperoleh pada perlakuan P0 (puree kacang merah 0\%) sebesar 1,45 dengan kriteria tidak suka. Hal ini dipengaruhi oleh perbedaan tingkat penambahan puree kacang merah, semakin tinggi penambahan puree kacang merah, maka tingkat penerimaan keseluruhan panelis akan semakin meningkat. Penerimaan keseluruhan nugget jamur tiram dipengaruhi oleh beberapa faktor seperti tekstur, aroma dan rasa. Hal ini menunjukan bahwa panelis dapat menerima nugget jamur tiram dari segi warna, aroma, tekstur dan rasa nugget jamur tiram.

\section{KESIMPULAN DAN SARAN}

\section{Kesimpulan}

Penambahan puree kacang merah pada pengolahan nugget jamur tiram memberikan pengaruh yang nyata terhadap kadar air, kadar abu, kadar protein, kadar serat kasar, terhadap uji hedonik aroma, rasa, tekstur (uji skoring dan hedonik) dan penerimaan keseluruhan. Perlakuan penambahan puree kacang merah terbaik pada penelitian ini yaitu nugget jamur tiram dengan penambahan puree kacang merah $40 \%$ dengan karakteristik seperti: kadar air 32.67, kadar abu 1,57\%, kadar serat kasar 6,47\%, kadar protein 7,29\%, aroma tidak suka, rasa suka, tekstur suka, tekstur kenyal dan penerimaan keseluruhan suka.

\section{DAFTAR PUSTAKA}

Achmad, M. 2011. Panduan Lengkap Jamur. Penebar Swadaya. Jakarta.

Adisarwanto, T. 2005. Tumbuhan Kacang-Kacangan. Penerbit Penebar Swadaya. Jakarta.

Agromedia. 2010. Bertanam Jamur Konsumsi. Agromedia Pustaka. Aneka Ilmu. Jakarta.

Agusta, F. K., D. F. Ayu, dan Rahmayuni. 2020. Nilai gizi dan karakteristik organoleptik nugget ikan gabus dengan penambahan kacang merah. Jurnal Teknologi Pangan. 14 (1) : 68-82.

Agustina,Nanik, S. Waluyo, Warji, Tamrin. 2013. Pengaruh suhu perendaman terhadap koefisien difusi dan sifat fisik kacang merah (Phaseolus vulgaris L.). Jurnal Teknik Pertanian Lampung $2(1): 35-42$.

Alamsyah, Y. 2007. Aneka Nugget Sehat Nan Lezat. Agro Media. Jakarta.

Andarwulan. N, F. Kusnandar, Herawati. D. 2011. Analisis Pangan. Dian Rakyat. Jakarta.

Astawan, M., 2009. Sehat Dengan Hidangan Kacang Merah Dan Biji-Bijian. Penebar Swadaya. Jakarta.

Aswar. 2005. Pembuatan fish nugget dari ikan nila merah (Oreochromis Sp.).Skripsi. Teknologi Hasil Perikanan. Fakultas Perikanan Bogor: Institut Pertanian Bogor. Bogor.

Badan Pusat Statistik. 2014. Statistik Produksi Holtikultura. Indonesia

Chazali, S. 2009.Usaha Jamur Tiram Skala Rumah Tangga. Penebar Swadaya. Jakarta.

Delvia, A. Z. 2017. Pemanfaatan Kacang Merah (Phaseolus Vulgaris L.) Dalam Pembuatan Nugget Sebagai Alternatif Makanan Jajanan Tinggi Protein Dan Kalsium Untuk Anak Sekolah Dasar. Skripsi. Jurusan Gizi. Politeknik Kesehatan Padang. Padang.

Huda, T dan H. T. Palupi. 2015. Mempelajari Pembuatan Nugget kacang merah. Jurnal Teknologi Pangan. 6 (1) : 36-42.

Justisia, S. R. W. A. H., dan A. C. Adi. 2016. Peningkatan daya terima dan kadar protein 
nugget substitusi ikan lele (clarias batrachus) dan kacang merah (vigna angularis). Media Gizi Indonesia. 11 (1) : 106-112.

Kusharto, C. M. (2006) Serat makanan dan peranannya bagi kesehatan. Jurnal Gizi dan Pangan. 1 (2) : 45-54.

Mahmud, M.K., Hermana, Nazarina, Marudut, S., Zulfianto, N.A., Muhayatun, Jahari, A.B., Permaesih, D., Ernawati, F., Rugayah, Haryono, Prihatini, S., Raswanti, I., Rahmawati, R., Santi, D.P., Permanasari, Y., Fahmida, U., Sulaem, A., Andarwulan, N., Atmarita, Almasyhuri, Nurjanah, N., Ikka, N.S., Sianturi, G., Prihastono, E., Marlina, L. 2018. Tabel komposisi pangan indonesia. direktorat jenderal kesehatan masyarakat. Direktorat Gizi Masyarakat. Kementerian Kesehatan Republik Indonesia.

Muchtadi, T. R dan Sugiyono. 1992. Ilmu pengetahuan bahan pangan. Institut Pertanian Bogor. Bogor.

Nurmalia. 2011. Nugget jamur tiram (Pleurotus ostreatus) sebagai alternatif makanan siap saji rendah lemak dan protein serta tinggi serat. Artikel penelitian tidak diterbitkan. Semarang. Fakultas Ilmu Gizi Kedokteran Universitas Diponegoro.
Rohaya, S. N. E. Husana, K. Bariah. 2013. Penggunaan bahan pengisi terhadap mutu nugget vegetarian berbahan dasar tahu dan tempe. Jurnal Teknologi dan Industri Pertanian Indonesia. 5 (1):8-16

Salunkhe, O. K., S. S. Kadam dan J. K. Chevan. 1985. Postharvest Biotechonology of Food Legume. $\mathrm{CRC} /$ Press Inc, Florida.

Saragih, R. 2015. Nugget Jamur Tiram (Pleurotus ostreatus) Sebagai Alternatif Pangan Sehat Vegetarian. E-Journal WIDYA Kesehatan dan Lingkungan. 1(2):90-95.

Soekarto, S.T. 1985. Penilaian Organoleptik Untuk Industri Pangan dan Pertanian. Bharata Karya Aksara. Jakarta.

Sumarmi. 2006. Botani dan tinjauan gizi jamur tiram putih. jurnal inovasi pertanian. 4 (2) : 124-130.

Sudarmadji, S. Haryono, B. Suhardi. 1997. Prosedur analisa untuk bahan makanan dan pertanian. Yogyakarta.

Sumardjo, D. 2009. Pengantar kimia: Buku Panduan Kuliah Mahasiswa Kedokteran dan Program Strata 1 Fakultas Bioeksakta. Jakarta.

Widyaningsih, T. D. Dan E. S. Murtini. 2006. Alternatif Pengganti Formalin Pada Produk Pangan. Trubus Agrisarana. Surabaya.

Winarno, F. G. 2008. Ilmu Pangan dan Gizi. PT. Gramedia Pustaka Utama. Jakarta. 